\title{
Differential gene expression and evidence of selective translation during anaerobic germination of Mucor racemosus sporangiospores
}

\author{
JohN E. LiNZ† and Michael ORLOWSKI* \\ Department of Microbiology, Louisiana State University, Baton Rouge, Louisiana 70803, USA
}

(Received 6 August 1990; revised 14 December 1990; accepted 4 January 1991)

\begin{abstract}
Anaerobically-germinated sporangiospores of Mucor racemosus develop into yeasts, whereas aerobicallygerminated sporangiospores become hyphae. Anaerobic germination was found to have the following traits in common with the previously characterized aerobic system of development: (i) immediate and vigorous protein synthesis upon exposure of the spores to liquid medium; (ii) a complete absence of RNA synthesis for the first 20 min of germination; and (iii) a mobilization of ribosomal subunits into active polyribosomes. The proteins synthesized in both systems during this 20 min interval must be specified by the pre-formed stable mRNA known to be stored in the dormant spore. The population of proteins manufactured early in anaerobic germination differed considerably from the set of proteins synthesized during the equivalent interval in air, suggesting that some unknown mechanism of selective translation must operate. A few dozen of the more prominent proteins could be categorized according to their patterns of synthesis during germination. This should allow future work to focus upon those genes and their products most closely linked to development. The most promising candidates include several proteins that are most conspicuous in the mature yeast and are among those proteins selectively translated in large amounts from stored mRNA templates during anaerobic germination.
\end{abstract}

\section{Introduction}

The zygomycete Mucor racemosus presents an especially advantageous microbial system in which to study eukaryotic development because, as in the morphogenetic pathways of most multicellular organisms, a single cell type (the sporangiospore) has the potential to differentiate into radically different alternative morphologies (Fig. 1). Moreover, as is true of higher organisms, this process of cell morphogenesis is dependent upon growth and the biosynthesis of many new gene products (Orlowski \& Sypherd, 1978; Linz \& Orlowski, 1982, $1984,1987)$. When stimulated with nutrients (which must include a hexose) in the absence of oxygen, the sporangiospores develop into spherical multipolar budding yeasts (Bartnicki-Garcia, 1973). The presence of oxygen, in as little as micromolar amounts, induces the sporangiospores to develop into coenocytic branching hyphae (Phillips \& Borgia, 1985). However, before either of the mature vegetative morphologies is realized, a

† Present address: Department of Food Science and Human Nutrition, Michigan State University, East Lansing, Michigan 48824, USA.

Abbreviation: YPG, yeast extract/peptone/glucose medium. several-hour period of undifferentiated spherical growth takes place.

This seeming absence of differentiation is apparent at the morphological level only, as a multitude of different proteins have been reported to newly appear while others disappear during this interval in air (Linz \& Orlowski, 1984, 1987). Protein synthesis commences immediately upon wetting of the spores, whereas RNA synthesis does not begin for at least $20 \mathrm{~min}$ (Linz \& Orlowski, 1982). A pool of stable mRNA that is synthesized during sporangiospore formation serves as the sole template for translation during this period, and perhaps for as long as $45 \mathrm{~min}$, when the first de novo-synthesized mRNA appears in polyribosomes (Linz \& Orlowski, 1982).

In the present study, we examined the pattern of protein synthesis during anaerobic germination of $M$. racemosus sporangiospores and compared it to the pattern observed in aerobically-germinated spores. As happens under air (Linz \& Orlowski, 1982, 1984, 1987), protein synthesis commenced in the anaerobic system as soon as the spores were wetted. This initial synthesis must have occurred from pre-existing mRNA templates because RNA synthesis did not begin for at least $20 \mathrm{~min}$. The population of proteins made in the anaerobic system differed profoundly from the assortment of proteins 


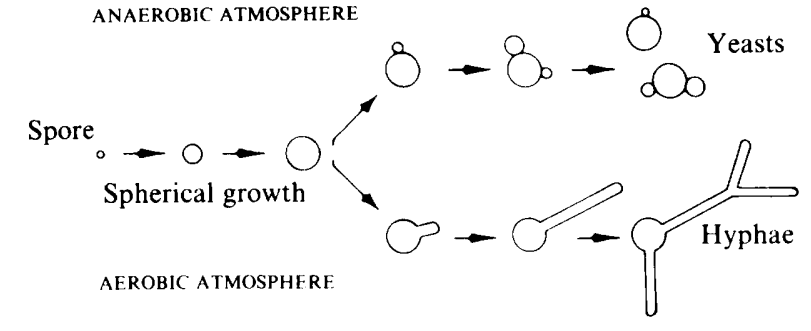

Fig. 1. Alternative morphogenetic fates of $M$. racemosus sporangiospores and atmospheric conditions controlling them.

synthesized in air. In many instances, proteins characteristic of mature yeasts or hyphae were preferentially synthesized and accumulated as soon as the spores were wetted and exposed to the appropriate gaseous environment. Since translation during most of the first half-hour (and probably beyond) is solely from stored mRNA templates, some mechanism allowing the spores to selectively translate specific sub-sets of the total set of stored mRNA must be operative.

\section{Methods}

Organism and sporangiospore production. $M$. racemosus $(M$. circinelloides) ATCC 1216B was used in all experiments. Sporangiospores were produced on YPG-agar medium in air as previously described (Linz \& Orlowski, 1982, 1984).

Germination. Sporangiospores were collected from agar plates directly into YPG-liquid medium as previously described (Linz \& Orlowski, 1982, 1984). Since the mere act of wetting the spores initiates germination, all kinetic measurements were timed from the moment the spores made contact with the medium. For aerobic germination, previously-aerated medium was used and the spore suspensions were shaken and sparged with compressed air as described earlier (Linz \& Orlowski, 1982, 1984). For anaerobic germination, agar plates bearing sporangiospores were equilibrated overnight in an anaerobic chamber containing pure nitrogen under positive pressure. Liquid medium was sparged with pure nitrogen for several hours to drive out all oxygen and was added to the spores in the anaerobic hood, where all further incubation and sampling were carried out. These suspensions were shaken and sparged continuously with pure nitrogen at a flow rate of 10 vols gas per vol. liquid per min.

Measurement of RNA and protein synthesis with radioactive precursors. The procedures of Linz \& Orlowski $(1982,1984)$ were used to follow the incorporation of $\left[{ }^{32} \mathrm{P}\right]$ phosphate or $\left[{ }^{3} \mathrm{H}\right]$ uracil and $\mathrm{L}-\left[{ }^{14} \mathrm{C}\right]$ leucine or $\mathrm{L}-$ $\left[{ }^{35} \mathrm{~S}\right]$ methionine into RNA and protein respectively. The radio-isotopes were added to the medium before its introduction to the spores. A leucine auxotroph (leu2A) was used when labelling with $\mathrm{L}-\left[{ }^{14} \mathrm{C}\right] l e u c i n e$.

Ribosome analysis. Samples of dormant and germinating spores were collected and treated with verrucarin and cycloheximide as described by Linz \& Orlowski (1982). Ribosome fractions were recovered from the spores and analysed on sucrose density gradients as described by Orlowski (1981).

Assay for protein. Protein was measured by the Lowry method, using bovine serum albumin as the standard.
Assay for protein turnover. Protein turnover was assayed by monitoring the release of radioactivity from the hot TCA-insoluble fraction of spores that had been pre-labelled with $L-\left[{ }^{14} \mathrm{C}\right]$ leucine or L- ${ }^{35}$ S $]$ methionine (Orlowski \& Sypherd, 1977, 1978)

Pre-labelling and pulse-labelling of sporangiospore proteins. Proteins were pre-labelled during sporangiospore formation on YPG-agar medium containing L- $\left[{ }^{35}\right.$ S $]$ methionine $\left(100 \mu \mathrm{Ci} \mathrm{ml}^{-1} ; 3 \cdot 7 \mathrm{MBq} \mathrm{ml}^{-1}\right)$. Spores were harvested directly into aqueous cycloheximide $(500 \mu \mathrm{g}$ $\mathrm{ml}^{-1}$ ). Proteins were pulse-labelled by harvesting spores directly into YPG-liquid medium and exposing them to $L-\left[{ }^{35} S\right]$ methionine $(160 \mu \mathrm{Ci}$ $\mathrm{ml}^{-1}$; $5.92 \mathrm{MBq} \mathrm{ml}{ }^{-1}$ ) for an appropriate $15 \mathrm{~min}$ interval during germination. Cycloheximde $\left(500 \mu \mathrm{g} \mathrm{ml}^{-1}\right)$ was added to the spore suspension at the end of each pulse. Four successive $15 \mathrm{~min}$ pulses were administered during the first $60 \mathrm{~min}$ of aerobic and anaerobic germination. The specific radioactivity of the free L-methionine pool was measured during each pulse period as previously described (Linz \& Orlowski, 1984)

Two-dimensional polyacrylamide gel electrophoresis (PAGE). Proteins were extracted from spores according to Hiatt et al. (1980), except that SDS was not included in the extraction buffer. PAGE was performed essentially as described by O'Farrell (1975). Samples contained $200 \mu \mathrm{g}$ protein labelled with approximately $10^{5}-10^{6}$ c.p.m. L- $\left[{ }^{35}\right.$ S $]$ methionine. First-dimension isoelectric focusing gels $(\mathrm{pH} 4.5$ to $7 \cdot 1 ; 120 \mathrm{~mm} \times$ $3 \mathrm{~mm}$ ) were subjected to $6800 \mathrm{~V} \times \mathrm{h}$. Second-dimension gels were composed of a $4 \%(w / v)$ polyacrylamide stacker $(5 \mathrm{~cm} \times 1.5 \mathrm{~mm})$ atop an $8-15 \%$ SDS-polyacrylamide gradient $(8 \mathrm{~cm} \times 1.5 \mathrm{~mm})$. Run time in the second dimension was $9 \mathrm{~h}$ at $20 \mathrm{~mA}$. Gels were fixed in methanol/ water/acetic acid $(5: 4: 1$, by vol.) and stained with Coomassie Blue R-250. After destaining, the gels were photographed, mounted on Whatman $3 \mathrm{MM}$ paper and dried under vacuum at $65^{\circ} \mathrm{C}$. Dried gels were autoradiographed with Kodak XAR-5 X-ray film at $-70^{\circ} \mathrm{C}$. Exposure was adjusted such that the product of radioactivity and time was equivalent to $10^{6}$ c.p.m. $\times 150$ h (Linz \& Orlowski, 1984, 1987).

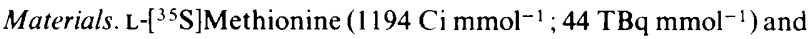
L- $\left[{ }^{14} \mathrm{C}\right]$ leucine $\left(289 \mathrm{mCi} \mathrm{mmol}^{-1}\right)$ were purchased from DuPont-New England Nuclear. $\left[{ }^{3} \mathrm{H}\right]$ Uracil $\left(32.5 \mathrm{Ci} \mathrm{mmol}^{-1} ; 10.69 \mathrm{TBq} \mathrm{mmol}^{-1}\right)$ and carrier-free $\left[{ }^{32} \mathrm{P}\right]$ phosphoric acid $\left(285 \mathrm{Ci} \mathrm{mg}^{-1} ; 10.54 \mathrm{~Bq} \mathrm{mg}^{-1}\right)$ were obtained from ICN Pharmaceuticals. Components of growth media were purchased from Difco. All other chemicals were obtained from Sigma or Bio-Rad.

\section{Results and Discussion}

\section{Kinetics of macromolecular synthesis during anaerobic sporangiospore germination}

Although measurements were made over more than $14 \mathrm{~h}$, the data presented in Fig. 2 are limited to the initial 60 min interval relevant to subsequent PAGE analyses. An increase in cell mass, represented as dry weight, began as soon as the spores were collected into liquid medium (Fig. 2). A constant doubling time of $3.0 \mathrm{~h}$ was maintained throughout spherical growth. This decreased to $2.3 \mathrm{~h}$ as growth accelerated somewhat when buds appeared. Protein synthesis, as measured by $\mathrm{L}-\left[{ }^{14} \mathrm{C}\right]$ leucine incorporation into hot TCA-insoluble material, commenced immediately, at an exponential rate commensurate with the growth rate (Fig. 2). Previous studies 


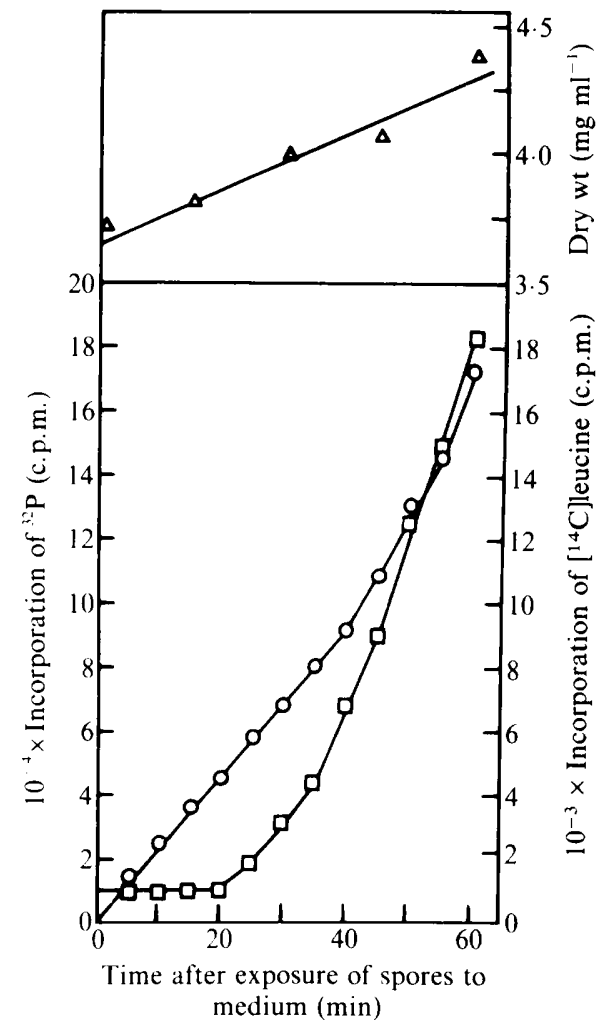

Fig. 2. Kinetics of cell mass accretion, RNA synthesis and protein synthesis during the first $60 \mathrm{~min}$ of anaerobic sporangiospore germination. Spores were harvested directly into de-oxygenated medium containing the appropriate radioactive precursor and incubated in the presence of pure nitrogen as described in the text. Samples were withdrawn from the suspension at intervals and assayed for the incorporation of radio-isotope into TCA-insoluble material as previously described (Linz \& Orlowski, 1982). Cell mass was determined by weighing the dehydrated residue of cells after washing them with water and baking them to dryness. $\triangle$, Cell dry weight; $\square$, c.p.m. of [ $\left.{ }^{32} \mathrm{P}\right]$ phosphate incorporated per $100 \mu \mathrm{l} ; \mathrm{O}$, c.p.m. of $\mathrm{L}-\left[{ }^{14} \mathrm{C}\right]$ leucine incorporated per $100 \mu \mathrm{l}$.

had characterized L-leucine pools and their very rapid equilibration with exogenous isotopically-labelled Lleucine in this organism under a variety of aerobic and anaerobic conditions (Orlowski \& Sypherd, 1977; Linz \& Orlowski, 1982). L-[ $\left.{ }^{35} S\right]$ Methionine, used as a label in PAGE analyses, displayed kinetics of pool equilibration and incorporation identical to those for $\mathrm{L}-\left[{ }^{14} \mathrm{C}\right]$ leucine (data not shown). RNA synthesis, as measured by [32 P]phosphate incorporation into cold TCA-insoluble material, displayed a lag of at least $20 \mathrm{~min}$ before it commenced upon an exponential increase (Fig. 2). It had previously been demonstrated that exogenous $\left[{ }^{32} \mathrm{P}\right]$ phosphate labels all ribose nucleotide triphosphate pools to steady-state levels in $M$. racemosus spores within $5 \mathrm{~min}$ (Linz \& Orlowski, 1982). Identical incorporation kinetics were observed for $\left[{ }^{3} \mathrm{H}\right]$ uracil (data not shown). Hence,

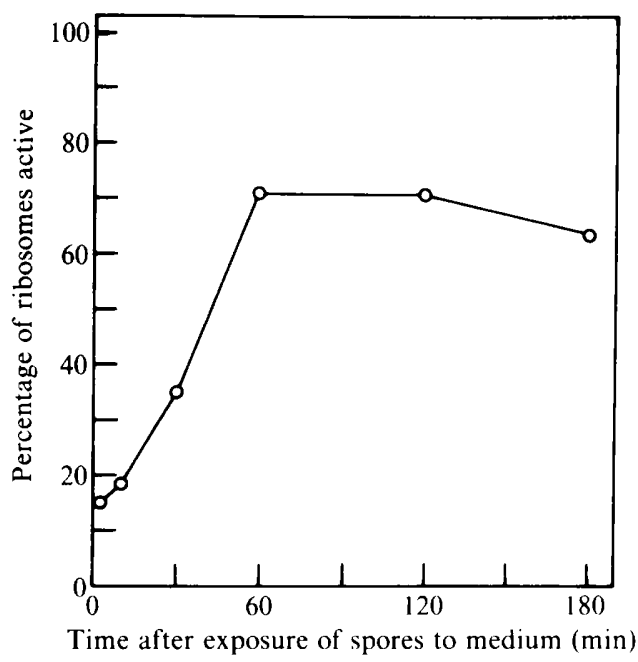

Fig. 3. Kinetics of ribosome activation during anaerobic sporangiospore germination. Ribosomes recovered from spore extracts were analysed on sucrose density gradients as previously described (Orlowski, 1981). Those contained within polyribosomes and nondissociable $80 \mathrm{~S}$ monosomes were interpreted as being bound to mRNA and, hence, active in protein synthesis (Martin, 1973).

we are convinced that the lag in RNA synthesis is real and that all protein synthesized during this interval is translated from a pool of stored mRNA previously demonstrated to exist in $M$. racemosus sporangiospores (Linz \& Orlowski, 1982, 1987).

\section{Kinetics of ribosome activation during anaerobic sporangiospore germination}

The percentage of ribosomes associated with mRNA polyribosomes plus $80 \mathrm{~S}$ monosomes non-dissociable at high ionic strength (Martin, 1973) - gradually increased from $15 \%$ in dormant spores to approximately $70 \%$ by $1 \mathrm{~h}$ after introduction of the spores to liquid medium (Fig. 3). The parameter maintained this value for several hours thereafter. The rate of ribosome activation was notably slower and the plateau values were somewhat lower under anaerobic conditions than we had previously observed in the presence of air (Linz \& Orlowski, 1982). This may simply be related to the slower rate of growth in the anaerobic system $\left(\mu=0.33\right.$ doublings $\left.h^{-1}\right)$ relative to the aerobic system $\left(\mu=0.50\right.$ doublings $\left.\mathrm{h}^{-1}\right)$. Alternatively, it may be associated with a mechanism for the selective initiation of translation on morphology-specific mRNAs. mRNAs critical to yeast development may already be bound to ribosomes in the dormant spore, whereas mRNAs essential for hyphal development may be recruited into polyribosomes only (but very rapidly) in the presence of oxygen. Evidence for selective translation of pre-formed mRNAs is presented below. 

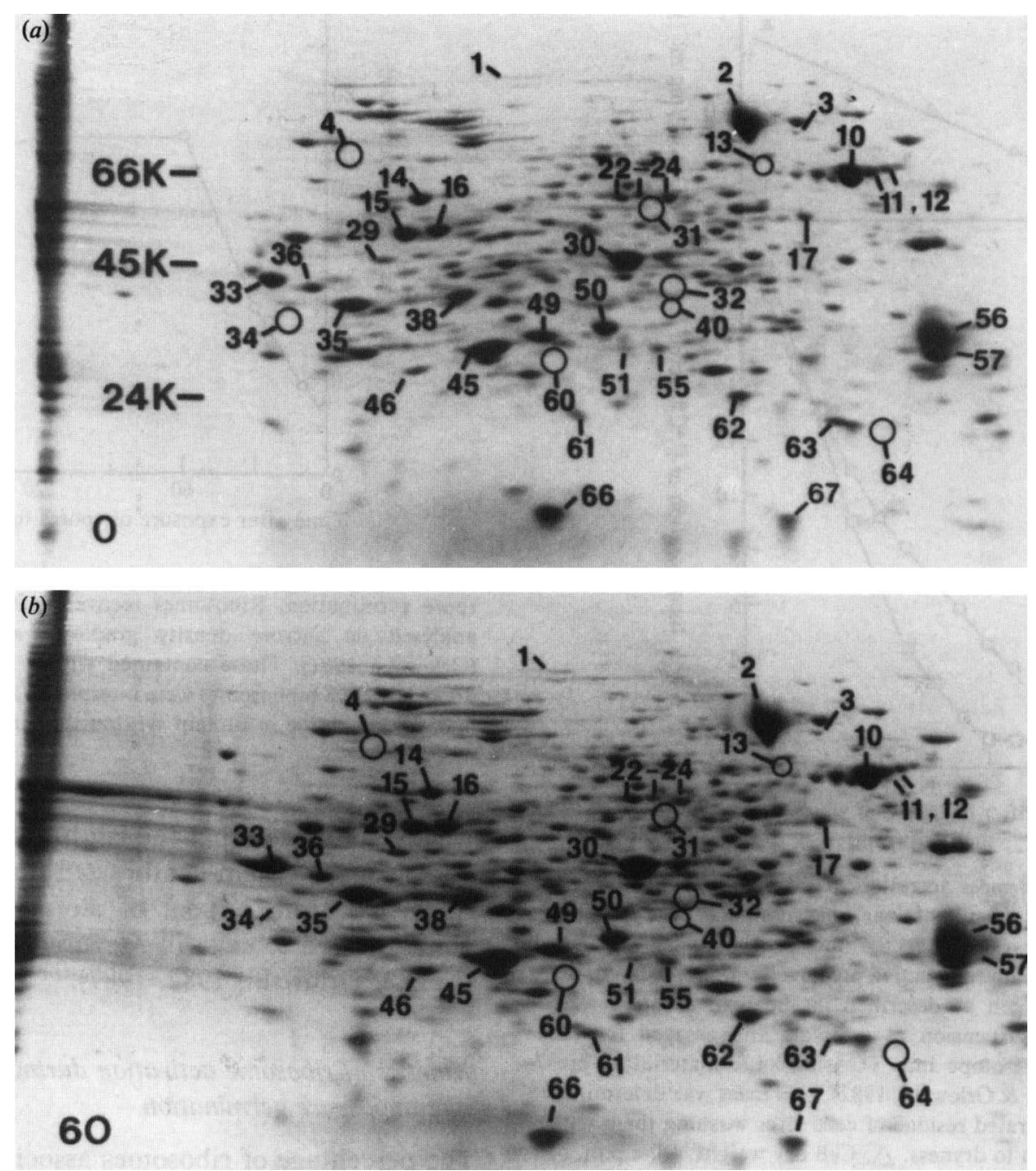

Fig. 4. Two-dimensional PAGE separation of proteins extracted from anaerobically germinating sporangiospores. Spores were harvested directly into sterile water containing cycloheximide $(a)$ or into de-oxygenated liquid medium followed by a 60 min period of incubation under pure nitrogen $(b)$. Proteins were extracted, electrophoresed, and stained with Coomassie Blue as described in the text. Circled areas represent missing proteins. The mobilities of molecular mass standards [bovine serum albumin, $66 \mathrm{KDa}(\mathrm{K})$; ovalbumin, $45 \mathrm{~K}$; and trypsinogen, $24 \mathrm{~K}]$ are indicated at the left of panel $(a)$. The measured $\mathrm{pH}$ gradient is indicated above panel $(a)$.

Two-dimensional PAGE analyses of proteins synthesized during aerobic and anaerobic sporangiospore germination

We estimate that two-dimensional PAGE resolved approximately 500 individual proteins, most of them present in relatively tiny amounts and most of them not showing any interesting changes during germination. However, several dozen proteins did provide good examples of gene products that appear to be regulated during the first hour of development. We have focused on as many of these that we could conveniently label on the figures. Additional examples of each category described below may be discovered by careful scrutiny of the electrophoretographs and autoradiographs (Figs 4-7).

It is important to make an initial distinction between the complement of proteins present within the germinating spore and those actively synthesized during a given interval. When we stained gels with Coomassie Blue, we found that the population of proteins present in the spore after $60 \mathrm{~min}$ of anaerobic germination was essentially the same as it had been in the dormant spore (Fig. 4). This was precisely the same result we had observed earlier in the aerobic system (Linz \& Orlowski, 1984). The only substantive change in either system was the appearance of a small amount of protein 34 , which is absent from the 
$\stackrel{n}{\dot{I}}$

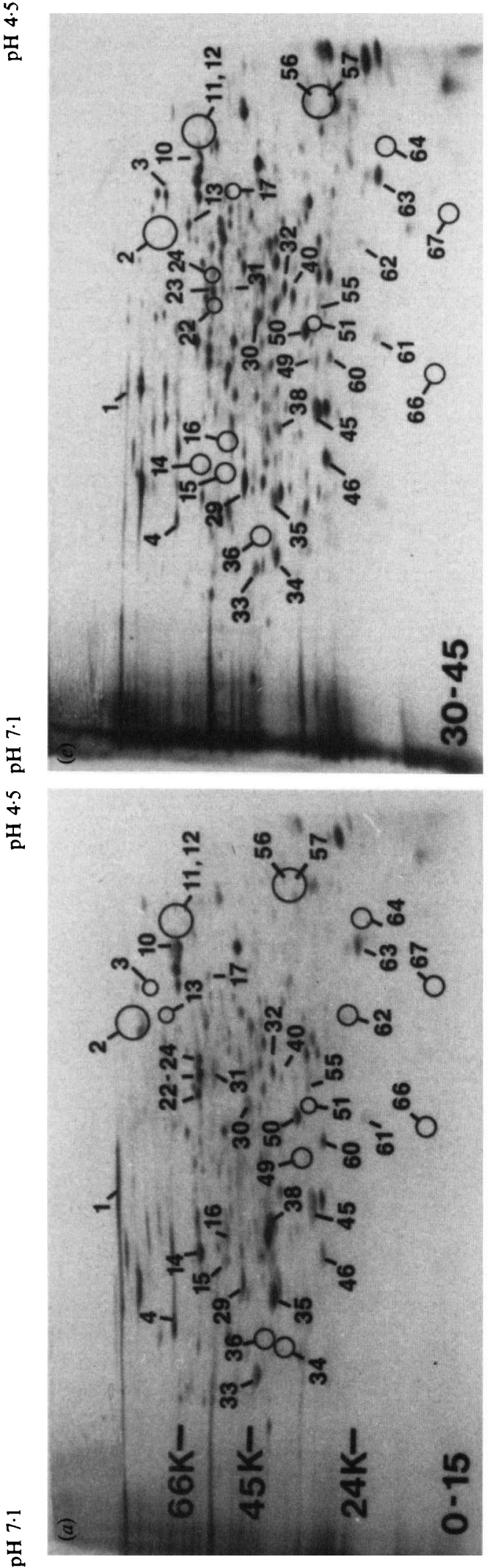

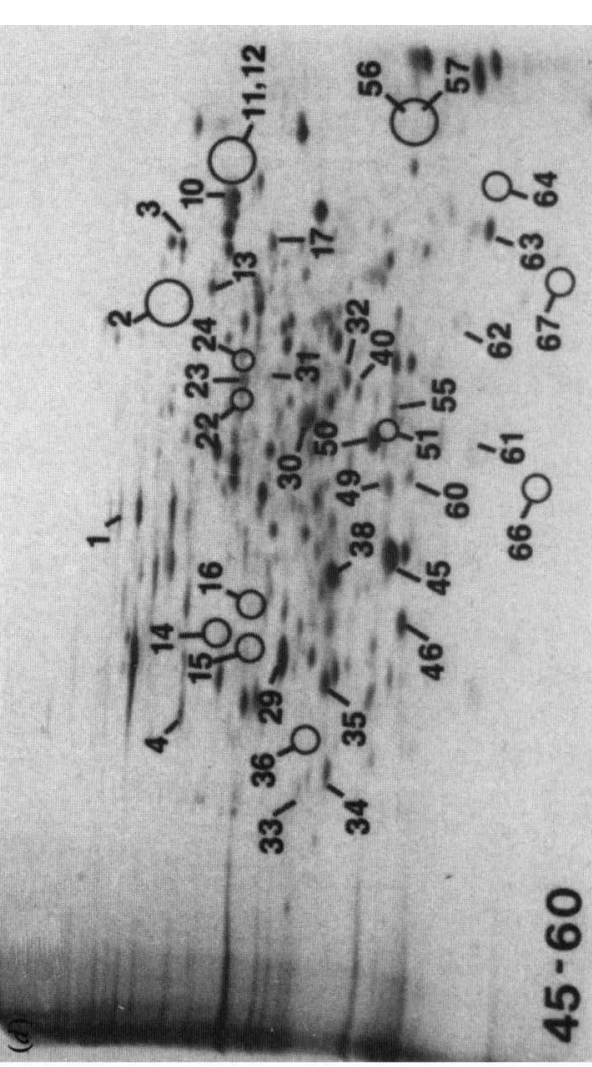

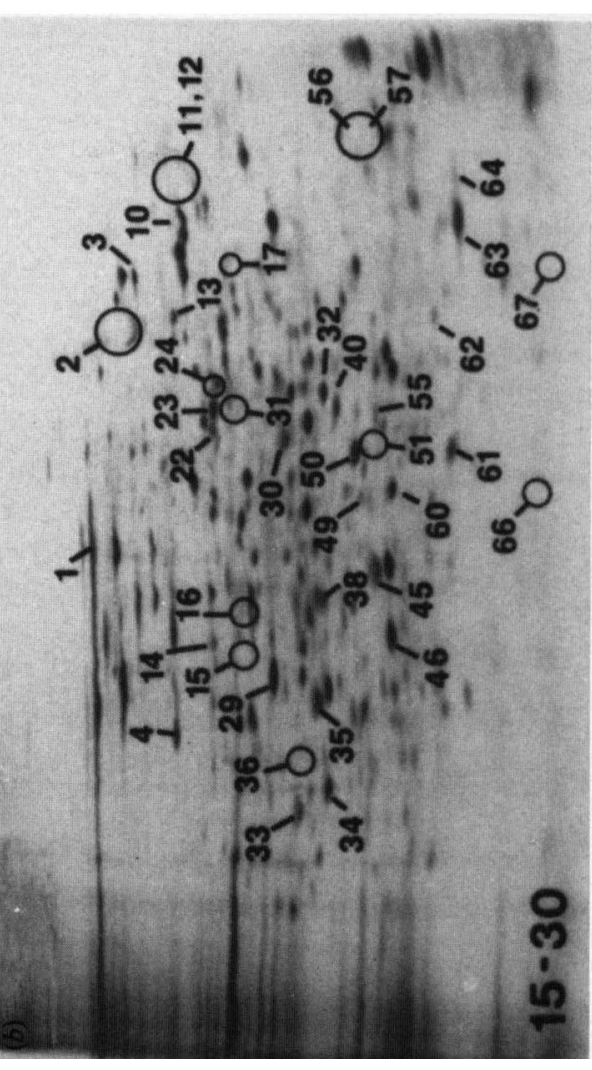

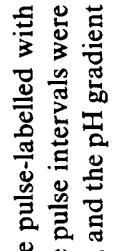

递它

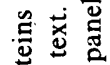

응

एن门

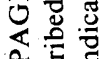

ส

(5)

更

要过

要要

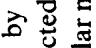

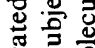

a क

政

○

5.

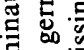

.

을

客

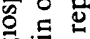

ํ.

要

的范焉

政

.

足节

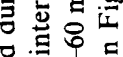
氙 毛 要

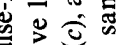

要要要

o

照

훈용

- 홍

옹을

를

o

影

苞高告

的寻

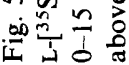


dormant spore. This protein was found to have arisen by post-translational modification of an unidentified precursor in aerobically-germinating spores (Linz \& Orlowski, 1984) and has the same origins here (data not shown). The significance of this is not known.

Examination of individual proteins, labelled with L$\left[{ }^{35} \mathrm{~S}\right]$ methionine in $15 \mathrm{~min}$ pulses throughout the first hour of aerobic and anaerobic germination, separated by PAGE, and made visible by autoradiography, revealed numerous qualitative and quantitative changes in protein synthesis (Figs 5 and 6) and led us to group these gene products into seven categories, based upon the pattern of their synthesis during development. The categories, as we recognize them, are individually characterized below and examples of each are given.

(i) Proteins whose synthesis is specific to spore formation. These proteins are present in the spore during early germination, having been carried over from spore formation, but are not actively synthesized during germination (Figs 4-6). This category would include proteins 2, 11, 12, 36, 56, 57, 66 and 67. Except for copious amounts of proteins 11 and 12 in both yeasts and hyphae, and minute traces of protein 66 in yeasts and protein 36 in hyphae, these proteins are also absent from both mature vegetative forms (Fig. 7). Whether the functioning of these proteins is also limited to spore formation, and inhibited during spore germination, is an interesting question that cannot yet be answered.

(ii) Proteins whose synthesis is specific to early spore germination in both aerobic and anaerobic systems. These proteins are absent, or nearly so, in dormant spores and mature vegetative forms, but are synthesized in significant amounts during early spherical growth regardless of the atmospheric composition (Figs 4-7). This category would clearly include proteins 4 and 31 . Proteins 13, 32, 34 and 60 are entirely absent from dormant spores but may be present in trace amounts in one or both of the vegetative forms. These proteins may play important roles in the early stages of germination common to both yeast and hyphal development, but are probably not determinants of the ultimate vegetative morphology.

(iii) Proteins whose synthesis is unique to aerobic or anaerobic germination. These proteins are synthesized only under one set of germination conditions and not the other (Figs 5 and 6). This category would include proteins 16,40 and 49 , which are synthesized only in the aerobic system. There were no conspicuous examples of proteins synthesized only in the anaerobic system. The latter observation would be consistent with the hypothesis presented above that all pre-formed mRNAs appropriate to anaerobic yeast development may already be bound to ribosomes in the dormant spore. Additional mRNAs necessary for aerobic hyphal development may be recruited into polyribosomes if oxygen is detected in the environment.

(iv) Proteins that may or may not be unique to germinating spores but whose rates of synthesis display profound changes during development. In aerobic germination this category would include proteins $1,3,10,13,14,15,16,17,22,24$, $29,30,31,33,34,38,40,45,46,49,60,61,62$ and 64 (Fig. $5)$. In anaerobic germination this group would encompass proteins $1,3,10,13,14,17,22,23,24,30,31,33,34$, $35,38,45,46,50,55,60,61,62$ and 64 (Fig. 6). These sets are not identical, although overlap is considerable. The specific patterns of change differ profoundly in the two systems for many of these proteins (see below).

(v) Proteins whose pattern of synthesis is unique to aerobic or anaerobic germination. These proteins may be synthesized under both conditions, but in very different amounts or in distinctly different patterns of flux. This category would include proteins $3,10,13,14,17,23,29,30,31,33$, $34,35,38,40,45,49,50,55,60,61,62$ and 64 (Figs 5 and 6). A reasonable hypothesis would be that they are all required for both yeast and hyphal development, but in differing amounts that can be finely adjusted.

(vi) Proteins not displaying any notable flux in their rate of synthesis throughout aerobic or anaerobic germination. Many of these are ubiquitous in dormant spores and in both vegetative forms. It is least likely that these gene products play roles in directing development. This category would include proteins 4,32 and 63 . There are many more examples of such proteins (e.g. the major protein southeast of protein 57 , or the three proteins directly west of protein 10 ), but they are not of much interest and have not been labelled.

(vii) Proteins clearly evidencing selective translation. If, as the data suggest, no RNA is synthesized for at least the first 20 min of germination, all protein must be translated from stored mRNA templates during this time. Therefore, any major differences in the quality or quantity of proteins synthesized during the first $15 \mathrm{~min}$ pulse interval must reflect selective translation. Since previous work had shown that de novo-synthesized mRNA did not appear in polyribosomes until $45 \mathrm{~min}$ of aerobic germination had elapsed (Linz \& Orlowski, 1982), selective translation might actually account for the observed patterns of protein synthesis through the first three 15 min pulse intervals. However, even assuming the more conservative first scenario, one can still discern that proteins 16 and 40 are immediately synthesized under aerobic but not anaerobic conditions, and that 

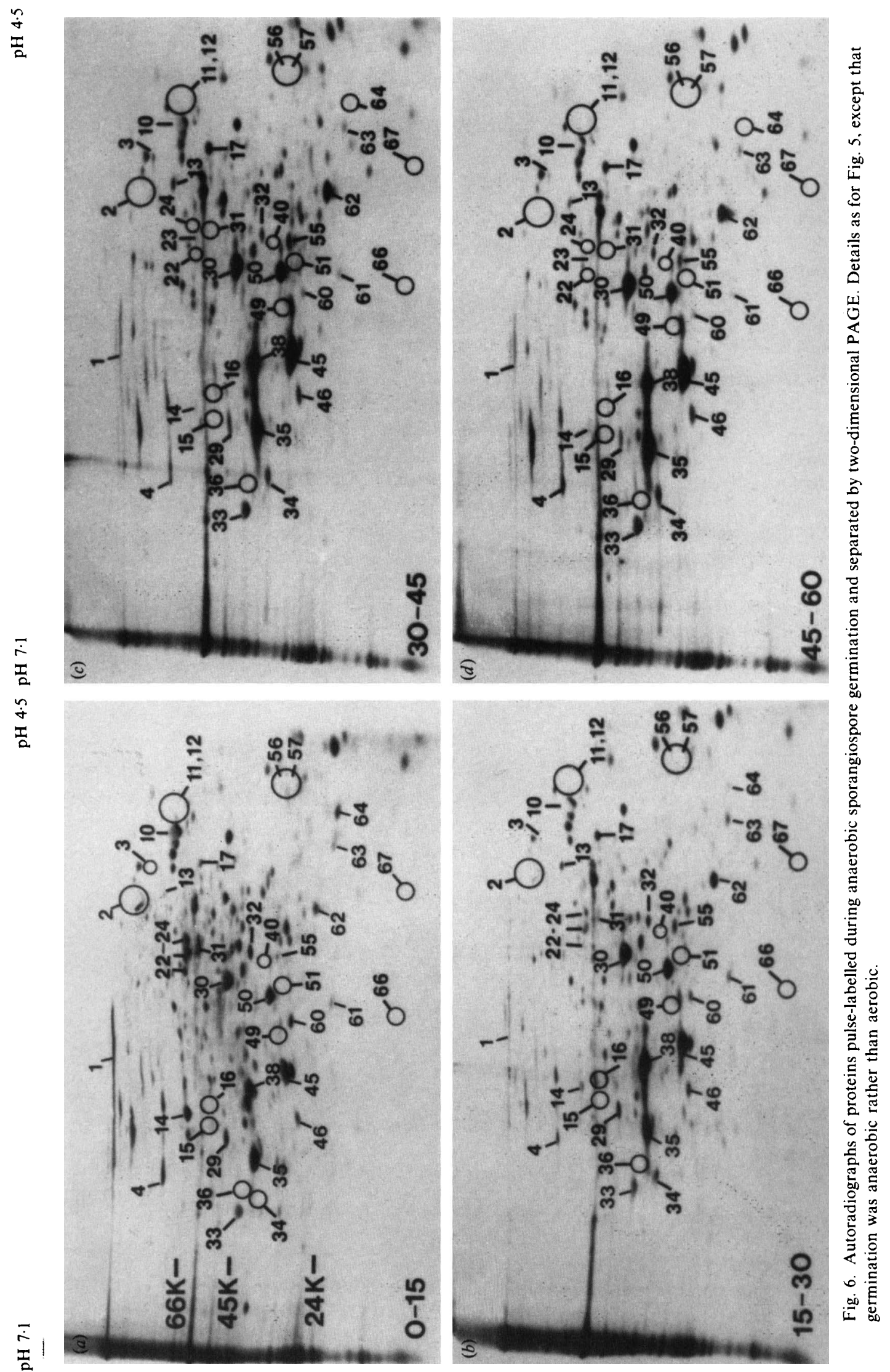



Fig. 7. Two-dimensional PAGE separation of proteins extracted from mature $M$. racemosus yeasts and hyphae. Early-exponentialphase yeasts were collected after $14 \mathrm{~h}$ of growth under pure nitrogen $(a)$. Young hyphae were collected after $16 \mathrm{~h}$ of growth under air $(b)$. Proteins were extracted, electrophoresed, and stained with Coomassie Blue as described in the text. Circled areas represent missing proteins. Molecular mass markers and the $\mathrm{pH}$ gradient are indicated on panel (a), and are the same as in Fig. 4.

proteins 13,62 and 64 are immediately synthesized under anaerobic but not aerobic conditions (Figs 5 and 6). One can locate several other excellent examples of this phenomenon by carefully scanning the autoradiographs (e.g. proteins south-southeast of 12 and north-northeast of 56). Major quantitative differences in the level of expression can be observed for proteins $29,30,31,35,38$, 45 and 50 (and an unlabelled protein east-northeast of 
31). In all instances, these proteins were synthesized in much greater amounts in the anaerobic system. PAGE analysis of proteins translated in vitro on RNA templates extracted from dormant $M$. racemosus sporangiospores showed that all of the protein products under present consideration were formed, implying the presence of the corresponding mRNAs (Linz \& Orlowski, 1987). If a protein is not made in vivo (as in the examples above), some mechanism must be specifically preventing translation of its mRNA. This blockage could occur at the level of initiation, elongation, or (least likely) chain termination and release. Oxygen, or a secondary messenger, may lift the putative block on translation of some proteins (16 and 40), whereas it may impose a block, of varying degree, on others $(13,29,30,31,35,38,45,50,62,64)$.

Proteolytic degradation or post-translational modifications were not the causes of the observed changes in protein populations during aerobic or anaerobic germination. Dormant sporangiospores pre-labelled with L$\left[{ }^{35} \mathrm{~S}\right]$ methionine and incubated with excess non-radioactive L-methionine did not release any radio-isotope during $60 \mathrm{~min}$ of incubation in liquid medium (data not shown). PAGE separation and autoradiography of proteins extracted before and after the 60 min incubation displayed no differences except for the appearance of protein 34, to which we referred earlier (data not shown).

Eventually, proteins 30, 33, 35, 38, 45, 50 and 62 became much more prominent in yeasts than in hyphae (Fig. 7). We would assume that they are of considerable importance to the developing anaerobic cell, since they are produced so rapidly and in such great abundance via selective translation of stored mRNAs. What functional roles these proteins may serve cannot be told at this time. It is not known if their levels are related to cell morphology or merely to cell metabolism. One possibility is that they may represent glycolytic enzymes necessary for the anaerobic fermentation of glucose. The isolation and analysis of germination mutants may help to solve this problem. Future work could focus on proteins with altered patterns of synthesis in the mutants.

Analysis of protein synthesis by two-dimensional PAGE has some limitations. Only 500 of the most abundant proteins are amenable to study. This is a relatively small portion of all proteins synthesized by the organism. Significant changes in less abundant proteins having profound effects on cell morphology may have been missed. However, this study did achieve its goal of describing a set of proteins whose expression is regulated in response to a single simple change in the cell environment which also directs cell morphogenesis. The use of recombinant DNA technology, in which genes relevant to development are identified and cloned, will be the approach of future research. A successful strategy might exploit the suppression of morphogenetic mutations by transformation with cloned DNA from a $M$. racemosus library. The regulation of single genes may then be studied at the molecular level. An understanding of gene regulation at the simplest level may enable one to model the more complex interplay of gene products and their effect on cell growth and morphology.

\section{References}

BARTNICKI-GARCIA, S. (1973). Fundamental aspects of hyphal morphogenesis. Symposia of the Society for General Microbiology 23, 245-267.

HiatT, W. R., INDERLied, C. B. \& SYPhERD, P. S. (1980). Differential synthesis of polypeptides during morphogenesis of Mucor. Journal of Bacteriology 141, 1350-1359.

LINZ, J. E. \& ORLOWSKI, M. (1982). Stored mRNA in sporangiospores of the fungus Mucor racemosus. Journal of Bacteriology 150, 11381144.

LinZ, J. E. \& ORLowski, M. (1984). Differential gene expression during aerobic germination of Mucor racemosus sporangiospores. Journal of Bacteriology 159, 965-972.

LINZ, J. E. \& ORLowsKI, M. (1987). Regulation of gene expression during aerobic germination of Mucor racemosus sporangiospores. Journal of General Microbiology 133, 141-147.

Martin, T. E. (1973). A simple general method to measure active ribosomes in eukaryotic cells. Experimental Cell Research 80, 496498.

O'Farrell, P. H. (1975). High resolution two-dimensional electrophoresis of proteins. Journal of Biological Chemistry 250, 4007-4021.

ORLOWSKI, M. (1981). Growth-rate-dependent adjustment of ribosome function in the fungus Mucor racemosus. Biochemical Journal 196, 403-410.

Orlowsk1, M. \& SyPHERD, P. S. (1977). Protein synthesis during morphogenesis of Mucor racemosus. Journal of Bacteriology 132, 209218.

ORLOWSKI, M. \& SYPHERD, P. S. (1978). Regulation of macromolecular synthesis during hyphal germ tube emergence from Mucor racemosus sporangiospores. Journal of Bacteriology 134, 76-83.

Phillips, G. J. \& BorgiA, P. T. (1985). Effect of oxygen on morphogenesis and polypeptide expression by Mucor racemosus. Journal of Bacteriology 164, 1039-1048. 